CHUCK JONES 

PORTRAITS OF AMERICAN GENIUS

We are a people.

A people do not throw their geniuses away. And if they are thrown away, it is our duty as artists and as witnesses for the future to collect them again for the sake of our children, and, if necessary, bone by bone.

Alice Walker 
TITLES PUBLISHED AND IN PRESS

Mabel McKay: Weaving the Dream
by Greg Sarris

Gene Roddenberry: The Last Conversation by Yvonne Fern

Chuck Jones: A Flurry of Drawings by Hugh Kenner 


\title{
Chuck Jones
}

\section{A FLURRY OF DRAWINGS}

\author{
Hugh Kenner
}


University of California Press

Berkeley and Los Angeles, California

University of California Press, Ltd.

London, England

(C) 1994 by

The Regents of the University of

California

Library of Congress

Cataloging-in-Publication Data

Kenner, Hugh.

Chuck Jones : a flurry of drawings /

Hugh Kenner.

p. cm.- (Portraits of American

genius ; 3 )

Includes bibliographical references and index.

ISBN 0-520-08797-6 (alk. paper)

I. Jones, Chuck,

1912- -Criticism and

interpretation.

I. Jones, Chuck, I9r2-

II. Title. III. Series.

NCr766.U52J6635 1994

741.5' $8^{\prime} \circ 92$-dc2o $93-48418$

CIP

Illustrations reprinted by permission of the artist. (C) 1994 Chuck Jones

Enterprises.

Printed in the United States of America

$\begin{array}{lllllllll}9 & 8 & 7 & 6 & 5 & 4 & 3 & 2 & 1\end{array}$

The paper used in this publication meets the minimum requirements of American National Standard for Information Sciences--Permanence of Paper for Printed Library Materials, ANSI Z39.48-r984. 
For Harry McCracken 
